\title{
Phosphate adsorption by mineral weathering particles in oligotrophic waters of high particle content
}

\begin{abstract}
Beat Müller, ${ }^{1}$ Ruth Stierli, ${ }^{1}$ and Alfred Wüest ${ }^{1}$
Received 15 February 2006; revised 11 May 2006; accepted 13 June 2006; published 11 October 2006.

[1] We investigated the interactions of dissolved reactive phosphorus (DRP) and dissolved nonreactive phosphorus (DNRP) with suspended and settled aquatic particles. The sorption to minerogenic particles from an alpine catchment collected in rivers, hydropower reservoirs, and a downstream ultraoligotrophic lake was modeled using Langmuir-type isotherms. DRP and DNRP exhibited about equal affinities to particle surfaces. The sorption of dissolved species to surfaces alters the fate of $\mathrm{P}$ in water bodies. In spite of the small surface-binding constants, high particle concentrations enhance the sorption of P to surfaces, and, consequently, chemical analysis of DRP can substantially underestimate the potentially bioavailable $\mathrm{P}$. In unpolluted rivers with high content of suspended mineral particles, e.g., triggered by heavy rain events $(2 \mu \mathrm{g} \mathrm{DRP} / \mathrm{L}, 1.3 \mathrm{~g} / \mathrm{L}$ suspended particles), P loads solely based on DRP measurements underestimate the true load of potentially bioavailable $\mathrm{P}$ by more than a factor of two. Modeling P sorption equilibria with a single type of surface site generates a management tool for water quality in P-limited oligotrophic systems.
\end{abstract}

Citation: Müller, B., R. Stierli, and A. Wüest (2006), Phosphate adsorption by mineral weathering particles in oligotrophic waters of high particle content, Water Resour. Res., 42, W10414, doi:10.1029/2005WR004778.

\section{Introduction}

[2] The productivity of most freshwater lakes is phosphorus (P)-limited [Schindler, 1977]. Phosphate that can readily be taken up by algae is defined operationally as the dissolved reactive $P(D R P)$ that during filtration, passes a $0.45 \mu \mathrm{m}$ pore size membrane [Wenzel, 2001]. Additionally, part of the nonreactive $\mathrm{P}$ (DNRP) (passing the filter but not being reactive with molybdenum) may become bioavailable after appropriate chemical transformations. Analytically, the DNRP consisting mainly of dissolved organic P (DOP) and colloidal $\mathrm{P}$ is the difference between the total dissolved $\mathrm{P}$ (TDP) analyzed after oxidative digestion of the filtrate minus DRP. As part of these dissolved $P$ species may reversibly sorb to particle surfaces ( $\equiv \mathrm{SP}$ ), also this particulate $\mathrm{P}$ fraction may contribute to the potentially bioavailable $\mathrm{P}$ pool.

[3] While sorption of $\mathrm{P}$ to synthetic Fe(III) minerals is well characterized [Dzombak and Morel, 1990], its sorption to natural particles is usually neglected due to the low affinity at ambient $\mathrm{pH}$ values [Baldwin et al., 2000], the low particle content $(<50 \mathrm{mg} / \mathrm{L}$ suspended particulates $)$ and their small specific surface area $\left(<10 \mathrm{~m}^{2} / \mathrm{g}\right)$. However, at low concentrations of free phosphate and high particle loads, the scavenging of dissolved P may significantly affect the physicochemical speciation and thus the fate of $\mathrm{P}$ within the aquatic environment. Input of riverine $\mathrm{P}$ to lakes is substantial during periods of high water discharge [Pacini and Gächter, 1999; Gächter et al., 2004], when concentrations of suspended particles can reach several $\mathrm{g} / \mathrm{L}$ and

\footnotetext{
${ }^{1}$ Surface Waters-Research and Management, Swiss Federal Institute of Aquatic Science and Technology, Kastanienbaum, Switzerland.

Copyright 2006 by the American Geophysical Union. 0043-1397/06/2005WR004778
}

TDP is increased 10 to 20 fold compared to low flow. In principle, if particles are small and settling is slow, sorbed $\mathrm{P}$ can be remobilized within the productive zone. Thus, as routine monitoring programs generally determine only the DRP and/or the TDP load but do not consider the fraction of reversibly sorbed $\mathrm{P}$, they may significantly underestimate the true load with $\mathrm{P}$ potentially available to their biota. Scavenged $\mathrm{P}$ may desorb during particle and/or TDP dilution or due to TDP consumption by primary producers. However, settling particles may also remove TDP from layers with elevated TDP concentrations, e.g., in an anoxic hypolimnion. In conclusion, the physicochemical speciation may be particularly important for surface waters poor in $\mathrm{P}$ such as high alpine streams, lakes and reservoirs [Ashley et al., 1997; Stockner and Macisaac, 1996] heavily loaded with mineral particles.

[4] An important prerequisite for physicochemical speciation is the availability of quantitative adsorption-desorption data applicable to natural particles at ambient $\mathrm{pH}$ values. Müller and Duffek [2001] suggested conditional adsorption parameters for several trace metal cations to natural aquatic particles and found them remarkably independent from particle composition. Surface sorption properties of anions to natural particles are, however, scarce. Sigg and Stumm [1981] described the adsorption of DRP to goethite, applying a detailed model of surface species including-binding constants and $\mathrm{pH}$ and allowing the extrapolation to natural waters. Goldberg [1985] modeled sorption competition between DRP, selenite and silicate on goethite. However, quantitative information on $\mathrm{P}$ sorption with particle surfaces other than iron or aluminum oxides is scarce. Ioannou and Dimirkou [1997] published surface-binding constants for DRP with kaolinite, a layer silicate. Millero et al. [2001] 


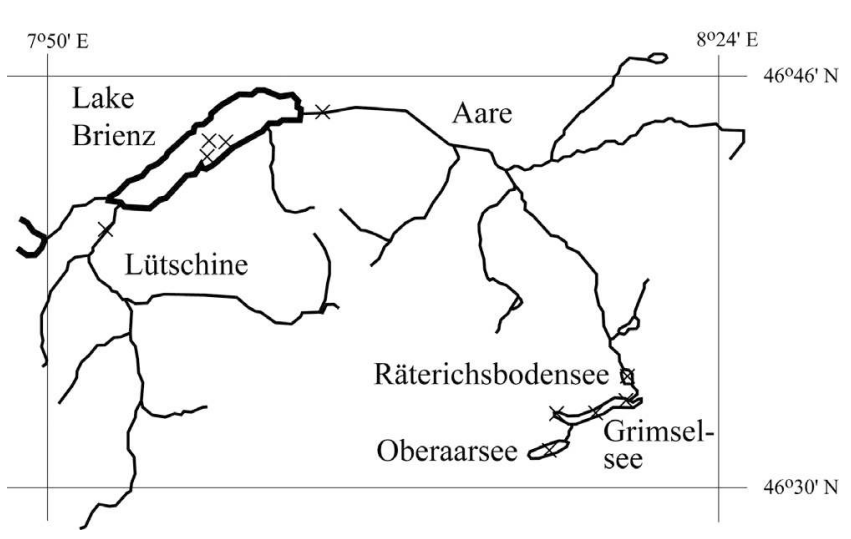

Figure 1. Map of the catchment of Lake Brienz (Switzerland) with the two main contributing rivers Aare and Lütschine. Oberaarsee, Grimselsee, and Räterichsbodensee are reservoirs built for hydropower production. Crosses indicate sampling sites.

provided very detailed data on $\mathrm{P}$ sorption onto calcite and aragonite.

[5] As it is questionable whether sorption constants derived from experiments with synthetic mineral phases are applicable to natural systems [Gustafsson, 2001], we determined the $\mathrm{P}$ sorption properties of a variety of natural suspended particles and sediment material in a concentration range where these inorganic surfaces may significantly compete with algae for bioavailable P. Sorption parameters resulting from our chemical equilibrium model and the experimental data are applied in discussing the P loads of the nutrient-poor and turbid rivers Aare and Lütschine, the main tributaries to Lake Brienz. This lake was subjected to distinct reoligotrophication due to $\mathrm{P}$ load reduction as well as to changes in the load of mineral particles as a consequence of the construction of reservoirs built for hydropower production (B. Müller et al., Past and present bio-available phosphorus budget in the ultra-oligotrophic Lake Brienz, submitted to Aquatic Science, 2006; A. Wüest et al., Quantifying non-inert phosphorus fluxes in particleladen ultraoligotrophic lakes, manuscript in preparation, 2006, hereinafter referred to as manuscript in preparation).

[6] The aim of our investigation was (1) to provide conditional sorption constants and surface-binding capacities describing the interaction of DRP with crystalline weathering particles encountered in rivers and lakes, (2) to relate the physicochemical parameters responsible for the sorption of phosphate to particle composition and specific surface area, (3) to estimate the fractions of dissolved and reversibly adsorbed $\mathrm{P}$ in particle loaded rivers, and (4) to discuss practical consequences for the estimation of loads and P budgets of ultraoligotrophic lakes.

[7] Our experimental attempt was twofold: (1) P desorption was measured from gradually diluted suspensions of 16 particle samples from lotic and lentic sites within the same watershed. Applying a chemical mass action law, the amount of reversibly bound $\mathrm{P}$ was obtained from this "mild" desorption procedure (by mere dilution and without using other ions to displace $\mathrm{P}$ ) together with a conditional surface-binding constant. (2) In adsorption experiments, suspended particles were "titrated" with increasing amounts of $\mathrm{P}$, resulting in a maximum surface-binding capacity and a conditional surface-binding constant for the situation of high surface coverage. The layout of the paper follows the order of the four aims of this investigation.

\section{Materials and Methods}

\subsection{Sampling Sites}

[8] Lake Brienz is an ultraoligotrophic ( $<4 \mu \mathrm{g} \mathrm{P} / \mathrm{L}$ [Organisation for Economic Co-operation and Development, 1982]), deep perialpine lake in Switzerland (Figure 1). It has a surface area of $29.8 \mathrm{~km}^{2}$, a volume of $5.17 \mathrm{~km}^{3}$, maximum depth of $260 \mathrm{~m}$ and average hydrological load of $62.3 \mathrm{~m}^{3} / \mathrm{s}$ (variability $\pm 50.4 \mathrm{~m}^{3} / \mathrm{s}$ ). While the Lütschine, one of the two major contributing rivers, drains a partly calcareous catchment of an unaltered hydrological regime, the Aare flows from a crystalline catchment whose flow is heavily altered by several reservoirs built for hydropower generation. The annual particle load is typically in the range of 250-350 kt (average $302 \mathrm{kt}$ ) and has decreased by approximately $232 \mathrm{kt} / \mathrm{yr}$ due to sedimentation in the reservoirs Grimselsee, Räterichsbodensee, and Oberaarsee [Finger et al., 2006; Anselmetti et al., 2006]. Grimselsee is a reservoir at $1904 \mathrm{~m}$ altitude with a small catchment of glaciers and rocks. Räterichsbodensee and Oberaarsee are in similar environments and are located down gradient and up gradient of Grimselsee, respectively. Corresponding to the different geology of the catchments, the $\mathrm{pH}$ in the reservoirs was around 7; in the Aare, Lütschine and Lake Brienz it was between 7.5 and 8.6. The sediment consists of clastic minerogenic particles. The composition of settling particles shows little seasonal variations. Thus $\mathrm{P}$ dissolution is precluded, and the repartitioning of $\mathrm{P}$ is constrained to adsorption and desorption reactions.

\subsection{Field Measurements}

[9] Discharge measurements in the Aare and Lütschine with a time resolution of $10 \mathrm{~min}$ were obtained from the Swiss Hydrological Survey of the Federal Office for Water and Geology (BWG/LHG) for 2003. Corresponding particle concentrations were used from Finger et al. [2006]. DRP concentrations were measured in two campaigns with high temporal resolution (1/h during floodwaters) and several month of occasional sampling (1/d). The continuous courses of DRP for 2003 were calculated in the same time resolution as discharge with a rating curve [Cohn, 1995; Moosmann et al., 2005] expressing the concentration as a function of discharge, as determined from monitoring data $\left(a+b Q^{c}\right.$, where $\mathrm{a}=1.75, \mathrm{~b}=0.13, \mathrm{c}=0.66$ for the Aare, $\mathrm{a}=0, \mathrm{~b}=$ $0.36, c=0.44$ for the Lütschine), where concentrations are in $[\mu \mathrm{g} \mathrm{P} / \mathrm{L}]$ and $\mathrm{Q}$ in $\left[\mathrm{m}^{3} / \mathrm{s}\right]$. Although sediments were sampled only once per year, the interannual variability in sediment composition is considered negligible for these lakes, because particles consist almost entirely of geogenic weathering material (consistently low organic content) that change over multiple timescales in concentration, but not in composition.

\subsection{Sampling, Sample Treatment, and Analysis}

[10] Samples of particulate matter were collected from various locations to obtain a representative set of particle compositions (Table 1). Settling particles were collected with cylindrical traps of $9.2 \mathrm{~cm}$ diameter and $75 \mathrm{~cm}$ length 
Table 1. Codes, Location, Date, Depth, and Positions of Sampling of Particulate Material Used for Sorption Experiments With Phosphate

\begin{tabular}{|c|c|c|}
\hline Code & Description & Date/Exposition/Position \\
\hline Grimsel inflow & Grimsel sediment, $3 \mathrm{~m}$ depth, inflow & 8 Oct 2003 \\
\hline Grimsel center & Grimsel sediment, $80 \mathrm{~m}$ depth, center & 8 Oct 2003 \\
\hline Grimsel outflow & Grimsel sediment, $45 \mathrm{~m}$ depth, outflow & 8 Oct 2003 \\
\hline Räterichsboden & Räterichsboden sediment & 27 May 2004 \\
\hline Oberaarsee & Oberaarsee sediment & 8 Oct 2003 \\
\hline BR03-1 $50 \mathrm{~m}$ & Lake Brienz, particle trap, $50 \mathrm{~m}$ & 20 Jun to 21 Aug 2003 \\
\hline BR03-2 $50 \mathrm{~m}$ & Lake Brienz, particle trap, $50 \mathrm{~m}$ & 25 Aug. -21 Oct 2003 \\
\hline BR03-1 $255 \mathrm{~m}$ & Lake Brienz, particle trap, $255 \mathrm{~m}$ & 12 May to 21 Aug 2003 \\
\hline BR03-2 $255 \mathrm{~m}$ & Lake Brienz, particle trap, $255 \mathrm{~m}$ & 25 Aug to 21 Oct 2003 \\
\hline BR04 $20 \mathrm{~m}(0-0.5)$ & Lake Brienz, sediment $20 \mathrm{~m}, 0-0.5 \mathrm{~cm}$ & 6 May $2004 /$ Pos. $640895 / 173967^{\mathrm{a}}$ \\
\hline BR04 $20 \mathrm{~m}(9-10)$ & Lake Brienz, sediment $20 \mathrm{~m}, 9-10 \mathrm{~cm}$ & 6 May $2004 /$ Pos. $640895 / 173967^{\mathrm{a}}$ \\
\hline BR04 $212 \mathrm{~m}(0-0.5)$ & Lake Brienz, sediment $212 \mathrm{~m}, 0-0.5 \mathrm{~cm}$ & 6 May 2004/Pos. $641150 / 174850^{a}$ \\
\hline BR04 212 m $(9-10)$ & Lake Brienz, sediment $212 \mathrm{~m}, 9-10 \mathrm{~cm}$ & 6 May 2004/Pos. $641150 / 174850^{a}$ \\
\hline Aare & Particles from floodwater & May 2005 \\
\hline Lütschine & Particles from floodwater & May 2005 \\
\hline Lütschine & Particles from floodwater & July 2005 \\
\hline
\end{tabular}

${ }^{\mathrm{a} P o s i t i o n s ~ i n ~ S w i s s ~ G r i d ~ c o o r d i n a t e s ~}$

exposed at depths of $50 \mathrm{~m}$ and $255 \mathrm{~m}$ in Lake Brienz. Sediment cores were collected with a gravity corer [Kelts et al., 1986] at $20 \mathrm{~m}$ and $212 \mathrm{~m}$ depth of Lake Brienz on 6 May 2004. Sediments from the reservoirs Grimselsee, Räterichsbodensee and Oberaarsee were grab sampled. Suspended particles from the Aare and Lütschine were collected during two storm events (May and July 2005). Coarse particles that settled within minutes were ignored, and suspended particles were subsequently harvested by filtration of 101 of floodwater using cellulose acetate membrane filters of $0.45 \mu \mathrm{m}$ pore size. Phosphate was determined photometrically with the molybdenum blue method following EN 1189:1996 [Deutsche Einheitsverfahren zur Wasseruntersuchung, 1996]. A $5 \mathrm{~cm}$ quartz cuvette was used, and the span of the calibration curve was $0.5-20 \mu \mathrm{g} \mathrm{P} / \mathrm{L}$, yielding a detection limit of approximately $0.3 \pm 0.2 \mu \mathrm{g} \mathrm{P} / \mathrm{L}$. Chemical analysis of TDP, TP and TN was performed after extraction of $25 \mathrm{~mL}$ of filtered water sample or about $50 \mathrm{mg}$ freeze-dried particulate sample with sodium hydroxide and potassium persulfate in an autoclave $\left(1 \mathrm{~h}, 120^{\circ} \mathrm{C}\right)$. Molybdatereactive phosphorus was then determined as described above. According to Lambert and Mahler [1995], the digestion procedure gives good recoveries up to $100 \mu \mathrm{g} \mathrm{P} / \mathrm{L}$. It is under discussion, however, whether mineral phases in the sample remain partly intact and retain P [Nollet, 2000]. TN was oxidized and present as $\mathrm{NO}_{3}^{-}$in the same extraction solution. $\mathrm{NO}_{3}^{-}$was determined photometrically at $540 \mathrm{~nm}$ with an autoanalyzer as nitrite $\left(\mathrm{NO}_{2}^{-}\right)$after passing a $\mathrm{Cd}-\mathrm{Cu}$ reductor and following the procedure EN 26777:1993 [Deutsche Einheitsverfahren zur Wasseruntersuchung, 1996]. The fractions of $\mathrm{P}$ and $\mathrm{N}$ that cannot be mineralized with this treatment may be irrelevant with respect of their bioavailability in the aquatic environment; however, one has to be aware that values for TP and TN depend on the analytical methods applied and on the quality of particles. Sediment was freeze-dried and the water content was determined from weight loss. A limited number of sorption experiments were performed with particles that were not freeze-dried to investigate the possible changes of particle properties, and results were within the range of parameters obtained with dried particles. The specific surface area of several samples was determined by BET- $\mathrm{N}_{2}$ adsorption at 77 K. Mass density was calculated from dry weight and volume (determined by the displacement of water in a volumetric flask). $\mathrm{Fe}, \mathrm{Mn}$ and $\mathrm{Ca}$ were determined with inductively coupled plasma and optical emission spectroscopy (ICP-OES, Spectro Ciros, Spectro Analytik) after acid digestion with $4 \mathrm{~mL}$ of concentrated, suprapure $\mathrm{HNO}_{3}$ (Merck) and $1 \mathrm{~mL} \mathrm{H}_{2} \mathrm{O}_{2}$ in a microwave oven. Accuracy levels based on rock standard samples were $10 \%$ for $\mathrm{Fe}$ and between $2 \%$ and $8 \%$ for $\mathrm{Mn}$ and $\mathrm{Ca}$, respectively. Total carbon (TC) and total organic carbon (TOC) were determined by combustion in an oxygen stream with a Heraeus elementar vario EL without treatment and after acidification with $5 \mathrm{M} \mathrm{HCl}$, respectively. Total inorganic carbon (TIC) was calculated as the difference between TC and TOC. The accuracy and reproducibility of the TC analysis were 5\% and $1.6 \%$, respectively.

\subsection{Phosphate Desorption Experiments}

[11] Stock suspensions of $100 \mathrm{~g} / \mathrm{L}$ were prepared by ultrasonification of freeze-dried particles for $15 \mathrm{~min}$ in $1 \mathrm{mM} \mathrm{NaHCO} 3$ solution to disperse conglomerates. Desorption was determined in $1 \mathrm{mM} \mathrm{NaHCO}{ }_{3}$ solutions at a $\mathrm{pH}$ of 8.6 containing particles at concentrations from $6 \mathrm{~g} / \mathrm{L}$ to $0.5 \mathrm{~g} / \mathrm{L}$. Suspensions were shaken for 40 to $70 \mathrm{~h}$ in the dark at $8{ }^{\circ} \mathrm{C}$. Samples were then $0.45 \mu \mathrm{m}$ membrane filtered, and DRP and TDP were determined as described above. The experiments were repeated up to three times; however, only the experiment where the titration curve fitted best to the model was used for evaluation.

[12] Surface-binding constants and maximum sorption capacities were determined from adsorption and desorption experiments for each of the 16 particle samples. Adsorption experiments reached high surface coverage (ratios phosphate $/$ particles $=0.8$ to $8 \mathrm{mmol} / \mathrm{kg}$ ), while desorption experiments covered a range of low phosphate/particle ratios $(0.1$ to $0.9 \mathrm{mmol} / \mathrm{kg})$. The sorption processes were described with Langmuir adsorption isotherms, where a distinct amount of surface-binding sites $\Gamma$ of the sorbent is occupied by the adsorbate $\mathrm{P}$ with a constant stoichiometry [Stumm and Morgan, 1996]. Pairs of parameters characterizing surface sorption (surface-binding constants $\mathrm{K}_{\mathrm{n}}$ and surface concentrations $\Gamma_{\mathrm{n}}$ ) obtained from desorption experiments revealed the actual surface concentration of DRP $\left(\mathrm{K}_{\mathrm{DRP}}, \Gamma_{\mathrm{DRP}}\right)$ and DNRP $\left(\mathrm{K}_{\mathrm{DNRP}}, \Gamma_{\mathrm{DNRP}}\right)$. 


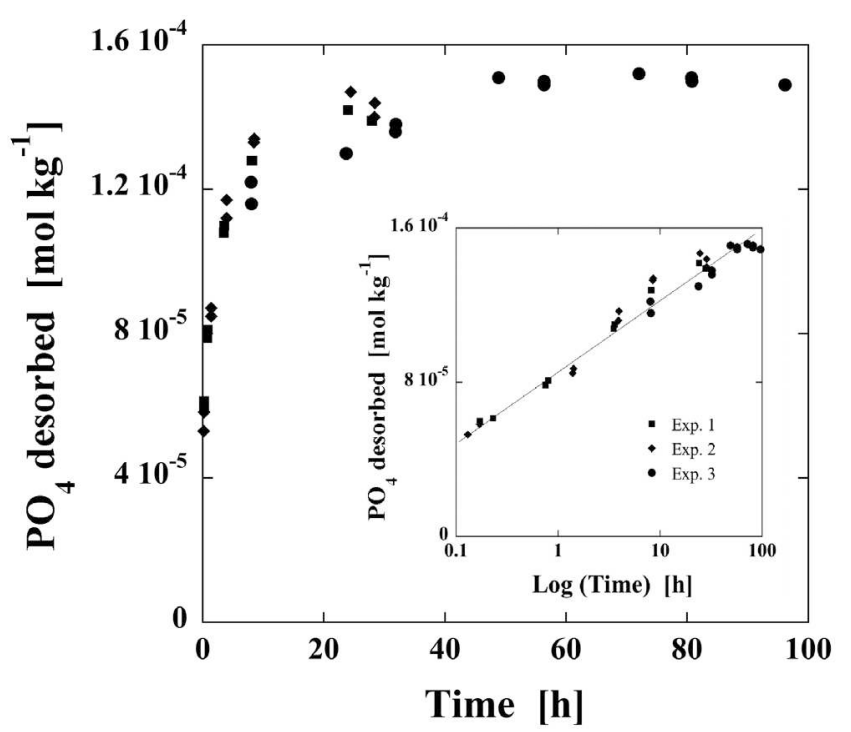

Figure 2. Three identical kinetic desorption experiments suspending $4 \mathrm{~g} / \mathrm{L}$ of sediment trap particles (BR03-2 $255 \mathrm{~m}$ ) in a solution of $1 \mathrm{mM} \mathrm{HCO}_{3}^{-}$. The inset depicts the logarithmic relation of the desorption process with time.

[13] The desorption process is formulated as a chemical mass action law with one type of adsorbent site (as an initial test of the hypothesis that adsorption on natural particles within this watershed can be adequately modeled by a single adsorbent):

$$
\begin{gathered}
\equiv S+P \Leftrightarrow \equiv S P \\
K_{n}=\frac{[\equiv S P]}{[\equiv S][P]}
\end{gathered}
$$

[14] The sorption constant, $K_{n}$, is conditional for the type of particles, the chemical composition of the solution in which the experiments were performed, and the range of phosphate concentrations. $\equiv \mathrm{S}$ depicts a surface sorption site, and $\equiv \mathrm{SP}$ a phosphate ion or complex adsorbed to the particle surface. $\mathrm{P}$ as well as the index $\mathrm{n}$ stand for DRP or DNRP. $\mathrm{TP}_{\mathrm{n}}$ of the experimental suspension consists of the sum of $\mathrm{P}$ and $\equiv \mathrm{SP}$ :

$$
T P_{n}=[P]+[\equiv S P],
$$

and the sum of surface sites $\mathrm{A} \Gamma_{\mathrm{n}}$ is

$$
A \Gamma_{n}=[\equiv S]+[\equiv S P]
$$

where $\mathrm{A}$ is the particle concentration in $\mathrm{g} / \mathrm{L}$ and $\Gamma$ is in $\mathrm{mol} / \mathrm{g}$.

[15] In order to determine the present surface concentration, the total occupied surface sites are set equal to the total remobilizable (reversibly adsorbed) P:

$$
A \Gamma_{n}=T P_{n}
$$

[16] Equations (2) -(5) were combined and rearranged to obtain the linear relationship (equation (6)) that was used to estimate values for $\mathrm{K}_{\mathrm{n}}$ and $\Gamma_{\mathrm{n}}$ from desorption experiments:

$$
\frac{A}{[P]}=\frac{1}{\Gamma_{n}}+\frac{K_{n}[P]}{\Gamma_{n}}
$$

\subsection{Phosphate Adsorption Experiments}

[17] Adsorption experiments contained a set of 12 samples of decreasing particle additions $(5-2.25 \mathrm{~g} / \mathrm{L})$ and simultaneously increasing $\mathrm{P}$ concentrations (2.5$17 \mu \mathrm{mol} / \mathrm{L}$ ) from a stock solution made of equivalent proportions of $\mathrm{NaH}_{2} \mathrm{PO}_{4}$ and $\mathrm{Na}_{2} \mathrm{HPO}_{4}$. The resulting $\mathrm{pH}$ of the suspensions was 8.5-8.6. These experiments pro-

\begin{tabular}{|c|c|c|c|c|c|c|c|c|c|c|}
\hline Sample & $\begin{array}{c}\text { Density, } \\
\mathrm{g} / \mathrm{cm}^{3}\end{array}$ & $\begin{array}{l}\mathrm{BET}, \\
\mathrm{m}^{2} / \mathrm{g}\end{array}$ & $\begin{array}{c}\mathrm{TP}, \\
\mathrm{mmol} / \mathrm{kg}\end{array}$ & $\begin{array}{c}\mathrm{TN}, \\
\mathrm{mmol} / \mathrm{kg}\end{array}$ & $\begin{array}{c}\text { TOC, } \\
\mathrm{mmol} / \mathrm{kg}\end{array}$ & $\begin{array}{c}\mathrm{TIC}, \\
\mathrm{mmol} / \mathrm{kg}\end{array}$ & $\begin{array}{c}\mathrm{TC} \\
\mathrm{mmol} / \mathrm{kg}\end{array}$ & $\begin{array}{c}\mathrm{Fe}, \\
\mathrm{mmol} / \mathrm{kg}\end{array}$ & $\begin{array}{c}\mathrm{Mn}, \\
\mathrm{mmol} / \mathrm{kg}\end{array}$ & $\begin{array}{c}\mathrm{Ca}, \\
\mathrm{Mmol} / \mathrm{kg}\end{array}$ \\
\hline \multicolumn{11}{|l|}{ Reservoir sediments } \\
\hline Grimselsee inflow & nd & nd & 26 & 1.3 & 41 & 19 & 60 & 408 & 6.9 & 244 \\
\hline Grimselsee center & nd & nd & 22 & 2.0 & 65 & 15 & 80 & 673 & 12 & 193 \\
\hline Grimselsee outlet & 2.64 & 2.09 & 18 & 4.6 & 125 & 31 & 156 & 694 & 15 & 232 \\
\hline Räterichsbodensee & nd & 2.86 & 19 & 6.7 & 178 & 73 & 251 & 647 & 14 & 268 \\
\hline Oberaarsee & nd & nd & 21 & 25 & 120 & 570 & 690 & 694 & 16 & 238 \\
\hline \multicolumn{11}{|c|}{ Lake Brienz suspended particles } \\
\hline BR03-1 $50 \mathrm{~m}$ & nd & 10.22 & 14 & 16 & 258 & 1417 & 1676 & 936 & 16 & 1502 \\
\hline BR03-2 $50 \mathrm{~m}$ & nd & nd & 15 & 14 & 256 & 1334 & 1591 & 897 & 15 & 1538 \\
\hline BR03-1 $255 \mathrm{~m}$ & 2.58 & 6.68 & 16 & 20 & nd & nd & 2761 & 726 & 13 & 2400 \\
\hline BR03-2 $255 \mathrm{~m}$ & nd & nd & 16 & 8.1 & 253 & 1801 & 2054 & 729 & 13 & 2378 \\
\hline \multicolumn{11}{|l|}{ Lake Brienz sediments } \\
\hline BR04 $20 \mathrm{~m}(0-0.5 \mathrm{~cm})$ & nd & nd & 18 & 39 & 334 & 1743 & 2077 & 897 & 15 & 1898 \\
\hline BR04 $20 \mathrm{~m}(9-10 \mathrm{~cm})$ & nd & nd & 21 & 34 & 33 & 1746 & 2076 & 843 & 15 & 1982 \\
\hline BR04 $212 \mathrm{~m}(0-0.5 \mathrm{~cm})$ & nd & 9.57 & 16 & 33 & 328 & 1361 & 1688 & 699 & 18 & 2498 \\
\hline BR04 $212 \mathrm{~m}(9-10 \mathrm{~cm})$ & nd & 8.16 & 17 & 35 & 338 & 1596 & 1934 & 690 & 13 & 3165 \\
\hline \multicolumn{11}{|l|}{ River suspended particles } \\
\hline Aare May 2005 & nd & nd & nd & nd & nd & nd & nd & 587 & 11 & 3000 \\
\hline Lütschine May 2005 & nd & nd & nd & nd & nd & nd & nd & nd & nd & nd \\
\hline Lütschine July 2005 & nd & nd & nd & nd & nd & nd & nd & 640 & 11 & 2850 \\
\hline
\end{tabular}
vide the maximum sorption capacity $\Gamma_{\max }$, and the binding constant $\mathrm{K}_{\max }$ at high $\mathrm{TP}_{\mathrm{n}}$ concentrations.

$$
A \Gamma_{\max }=[\equiv S]+[\equiv S P]
$$

Table 2. Chemical and Physical Composition of Samples of Particulate Matter Used for P Sorption Experiments ${ }^{\mathrm{a}}$

${ }^{\mathrm{a}}$ Here nd indicates not determined. 
Table 3. Surface-Binding Constants and Actual Surface Concentrations of DRP $\left(\log K_{\mathrm{DRP}}, \Gamma_{\mathrm{DRP}}\right)$, DNRP $\left(\log \mathrm{K}_{\mathrm{DNRP}}, \Gamma_{\mathrm{DNRP}}\right)$, and TP $\left(\log \mathrm{K}_{\mathrm{TP}}, \Gamma_{\mathrm{TP}}\right)$ as Determined by Desorption Experiments ${ }^{\mathrm{a}}$

\begin{tabular}{|c|c|c|c|c|c|c|c|c|}
\hline \multirow[b]{2}{*}{ Sample Quality and Origin } & \multicolumn{6}{|c|}{ Desorption Experiments } & \multicolumn{2}{|c|}{ Adsorption Experiments } \\
\hline & $\log \mathrm{K}_{\mathrm{DRP}}$ & $\Gamma_{\text {DRP }}, \mathrm{mmol} / \mathrm{kg}$ & $\log K_{\text {DNRP }}$ & $\Gamma_{\text {DNRP }}, \mathrm{mmol} / \mathrm{kg}$ & $\log \mathrm{K}_{\mathrm{TDP}}$ & $\Gamma_{\mathrm{TDP}}, \mathrm{mmol} / \mathrm{kg}$ & $\log \mathrm{K}_{\max }$ & $\Gamma_{\max }, \mathrm{mmol} / \mathrm{kg}$ \\
\hline \multicolumn{9}{|l|}{ Reservoir sediments } \\
\hline Grimselsee inflow & 7.21 & 0.16 & 6.89 & 0.02 & 7.11 & 0.21 & 6.16 & 0.23 \\
\hline Grimselsee center & 6.83 & 0.24 & 7.51 & 0.08 & 6.64 & 0.28 & 6.28 & 0.42 \\
\hline Grimselsee outlet & 6.57 & 0.33 & 6.97 & 0.09 & 6.54 & 0.49 & 6.24 & 0.81 \\
\hline Räterichsbodensee & 6.2 & 0.22 & 6.44 & 0.12 & 6.16 & 0.38 & 6.69 & 0.6 \\
\hline Oberaarsee & 6.37 & 0.3 & 6.98 & 0.29 & 6.25 & 0.51 & 6.27 & 0.61 \\
\hline Average \pm SD & $6.49 \pm 0.27$ & $0.27 \pm 0.05$ & $6.98 \pm 0.44$ & $0.15 \pm 0.09$ & $6.40 \pm 0.23$ & $0.41 \pm 0.11$ & $6.37 \pm 0.22$ & $0.61 \pm 0.16$ \\
\hline \multicolumn{9}{|c|}{ Surface sediments and settling particles from Lake Brienz and suspended particles collected in its tributaries } \\
\hline BR03-1 $50 \mathrm{~m}$ & 6.39 & 0.39 & 5.97 & 0.18 & 5.93 & 0.54 & 5.65 & 1.4 \\
\hline BR03-2 $50 \mathrm{~m}$ & 6.12 & 0.31 & 5.55 & 0.16 & 5.55 & 0.43 & 5.81 & 1.2 \\
\hline BR03-1 $255 \mathrm{~m}$ & 6.55 & 0.38 & 6.44 & 0.23 & 6.02 & 0.47 & 5.74 & 1.7 \\
\hline BR03-2 $255 \mathrm{~m}$ & 6.41 & 0.31 & 5.96 & 0.12 & 5.93 & 0.39 & 5.75 & 1.6 \\
\hline BR04 $20 \mathrm{~m}(0-0.5 \mathrm{~cm})$ & 5.77 & 0.4 & 5.57 & 0.25 & 5.4 & 0.65 & 5.61 & 1.1 \\
\hline BR04 $212 \mathrm{~m}(0-0.5 \mathrm{~cm})$ & 6.01 & 0.41 & 5.84 & 0.18 & 5.79 & 0.63 & 5.7 & 1.2 \\
\hline Aare May 2005 & 6.56 & 0.88 & nd & nd & nd & nd & 6.06 & 1.3 \\
\hline Lütschine May 2005 & 7.05 & 0.41 & 7.17 & 0.32 & 6.83 & 0.76 & 5.68 & 1.3 \\
\hline Lütschine July 2005 & 6.19 & 0.91 & 7.22 & 0.1 & 6.09 & 0.93 & nd & nd \\
\hline Averages \pm SD & $6.34 \pm 0.37$ & $0.49 \pm 0.23$ & $6.22 \pm 0.67$ & $0.19 \pm 0.07$ & $5.82 \pm 0.25$ & $0.60 \pm 0.18$ & $5.75 \pm 0.14$ & $1.35 \pm 0.21$ \\
\hline \multicolumn{9}{|c|}{ Subsurface sediments of Lake Brienz } \\
\hline BR04 $20 \mathrm{~m}(9-10 \mathrm{~cm})$ & 5.83 & 1.03 & 6.83 & 0.25 & 5.55 & 1.04 & 5.72 & 1.2 \\
\hline BR04 $212 \mathrm{~m}(9-10 \mathrm{~cm})$ & 5.63 & 0.98 & 6.14 & 0.22 & 5.5 & 1.16 & 5.61 & 1.2 \\
\hline Averages \pm SD & $5.73 \pm 0.14$ & $1.01 \pm 0.04$ & $6.48 \pm 0.49$ & $0.23 \pm 0.03$ & $5.53 \pm 0.04$ & $1.10 \pm 0.08$ & $5.66 \pm 0.08$ & $1.21 \pm 0.06$ \\
\hline
\end{tabular}

\footnotetext{
${ }^{a}$ Adsorption experiments represent surface sorption constants for high surface coverage and maximum sorption capacities (log $\left.K_{\max }, \Gamma_{\max }\right)$. Numbers in
} italics were omitted for the calculation of averages. Here nd indicates not determined. For sample identification, see Table 1.

Insertion in equation (2) and rearrangement lead to

$$
\frac{A[P]}{[\equiv S P]}=\frac{1}{K_{\max } \Gamma_{\max }}+\frac{[P]}{\Gamma_{\max }}
$$

If this linear relation between measured DRP and the term on the left hand side of the equation is fitted to experimental data, $\Gamma_{\max }$ and $\mathrm{K}_{\max }$ result from the slope and the intercept with the y axes, respectively.

[18] The kinetics of $\mathrm{P}$ desorption from particulate surfaces was investigated by incubation of a $4 \mathrm{~g} / \mathrm{L}$ suspension of trap material (BR03-1 $255 \mathrm{~m}$ ) at $5^{\circ} \mathrm{C}$ in the dark for $100 \mathrm{~h}$. Desorption of phosphate reached $95 \%$ of the long-term equilibrium after $20 \mathrm{~h}$ (Figure 2).

[19] The program ChemEQL [Müller, 2004] was applied to asses chemical equilibria and to model surface sorption.

\section{Results}

\subsection{Physical and Chemical Particle Characterization}

[20] Table 2 characterizes the particle composition. Most obvious is the much lower $\mathrm{Ca}, \mathrm{TN}$, TOC and TIC content and BET surface of the particles from the crystalline Grimselsee catchment area compared to those collected in Lake Brienz and its direct tributaries. In contrast, the extractable TP content of all particles was very similar.

\subsection{Surface Sorption Parameters}

[21] Desorption and adsorption experiments were clustered in three groups of surface-binding constants describing the interaction of particle surfaces with (1) dissolved reactive $P$ (DRP), (2) dissolved nonreactive $P$ (DNRP), and (3) total dissolved P (TDP). In addition, the adsorption experiments provided the maximum DRP sorption capacity of the investigated particles and the associated complexation constants at high surface coverage (Table 3). Interestingly, binding constants $(\log \mathrm{K})$ of both, sorption and desorption experiments, were very similar despite different amounts of sorbed inorganic P. As the binding constant expresses the inner sphere interaction between the surface ligand site and the sorbing inorganic phosphate anion, these similarities indicate that the chemical structure of the surface-binding sites were quite uniform within the three groups of investigated particles. The maximum sorption capacities that resulted from adsorption experiments were only about $50-100 \%$ higher than the actual surface concentrations found by the desorption experiments, indicating that even in these low dissolved $\mathrm{P}$ environments a substantial fraction of the available P-binding sites was already occupied. Surprisingly, adsorption constants for DRP and DNRP were similar, suggesting a similar type of chemical interaction of organically bound $\mathrm{P}$ or poly $\mathrm{P}$ with the particulate surface as for the inorganic phosphate ion.

[22] Sorption constants and surface-binding capacities from desorption experiments classify the investigated particle samples in three categories, namely, (1) settling particles and surface sediments of Lake Brienz and riverine particles, (2) lake sediments from 9 to $10 \mathrm{~cm}$ depth, and (3) sediments from the high alpine reservoirs (Table 3 ).

[23] Comparison of the contents of total P (Table 2) and total desorbable $\mathrm{P}$ (Table 3 ) indicates that only about $2 \%$, 3 to $4 \%$ and 5 to $7 \%$ of the particles' total $\mathrm{P}$ was readily desorbable in the sediment of the reservoirs, the surface sediment and settling particles of Lake Brienz, and its subsurface sediment, respectively. 60 to $80 \%$ of the total desorbable P consisted of DRP, while 20 to $40 \%$ was DNRP (Table 3).

\subsection{Surface Sorption and Particle Composition}

[24] BET measurements suggest that particle surfaces of reservoir sediments were 3-5 times per mass unit smaller than Lake Brienz particles (Table 2). The same trend is also 
expressed in the maximum adsorption capacities, $\Gamma_{\max }$ (Table 3), which were all clearly larger for Lake Brienz particles $(1.1-1.7 \mathrm{mmol} / \mathrm{kg})$ than for the samples from the reservoirs $(0.23-0.81 \mathrm{mmol} / \mathrm{kg})$. The high density and low TOC content especially of the reservoir particles confirm their predominantly mineral nature. Quartz, mica, feldspars and calcite are the main mineral constituents of the suspended particles and sediments of Lake Brienz. All these minerals, except calcite, which dominates preferentially in Lütschine, adsorb $\mathrm{P}$ poorly [Stone and Mudroch, 1989].

[25] The narrow concentration range of desorbable $P$ (Table 3) and of other constituents (Table 2) observed in settling particles obtained from different depths indicates that little mineralization occurred during settling across the hypolimnion. This is plausible as the average residence time of particles in the water column of Lake Brienz was estimated at only $14 \mathrm{~d}$ (Wüest et al., manuscript in preparation, 2006). Surprisingly, the TOC content of sediment samples $(333 \pm 4 \mathrm{mmol} / \mathrm{kg})$ exceeded that of settling particles $(256 \pm 3 \mathrm{mmol} / \mathrm{kg})$ by about $30 \%$. The amount of desorbable $\mathrm{P}$ did not change significantly between the upper $(0.49 \mathrm{mmol} / \mathrm{kg})$ and lower $(0.43 \mathrm{mmol} / \mathrm{kg})$ sediment traps, which is in line with the small changes of dissolved phosphate concentrations measured in the water column (Wüest et al., manuscript in preparation, 2006). However, the older sediment collected in the zone between 9 and $10 \mathrm{~cm}$ depth contained almost twice as much desorbable $\mathrm{P}$ as the settling particles and the surface sediment. This suggests that early diagenesis resulted in $\mathrm{P}$ transformations that increased the amount of desorbable P. The lowest desorbable P content was found for the Grimselsee sediment. The contents were clearly graded, as the sample near the glacier meltwater inflow gave the lowest value and the particles sampled at the dam the highest. The content of both TOC and TIC were low and the density of the material very high, thus confirming the mineral nature of the particulate matter (Table 2).

\subsection{Kinetics of Adsorption and Desorption Processes}

[26] Kinetic experiments revealed a fast initial step of desorption $(50 \%$ of the equilibrium is reached within less than $1 \mathrm{~h}$ ) and a subsequent slower phase, with a $\tau_{95}$ (time when $95 \%$ of the final equilibrium concentration is attained) of $20 \mathrm{~h}$ (example shown in Figure 2). The temporal desorption isotherm fits a logarithmic function (inset in Figure 2). In the adsorption process, an initially fast phase followed by a slower phase was always observed [Fox and Malati, 1993; Millero et al., 2001]. Moreover, desorption processes were found to be much slower than adsorption processes [Goldberg and Sposito, 1985]. Colombo et al. [1994] suggested that slow adsorption and desorption processes (hours to days) occur preferentially at surfacebinding sites with lower affinity toward phosphate. As the timescale of the adsorption/desorption processes determined in laboratory experiments (hours) is shorter than the timescale of floodwaters or rain events where settled river particles are resuspended and transported to the lake or settle through its water column (days), we assume sorption/ desorption equilibria to be established in the rivers and lake, with minimal changes in chemical composition and no water column redox gradients observed in the lakes (Wüest et al., manuscript in preparation, 2006).

\subsection{DRP Concentrations in Lake Brienz and Its Tributaries}

[27] DRP concentrations varied between $0.3-2.3 \mu \mathrm{g} \mathrm{P} / \mathrm{L}$ in the water column of Lake Brienz. Vertical concentration profiles of DRP and TP are given by Wüest et al. (manuscript in preparation, 2006). Measurement campaigns in the Aare and Lütschine with high temporal resolution (one sample per hour) exhibited DRP concentrations of 1 to $5 \mu \mathrm{g} / \mathrm{L}$ with exceptional peaks not higher than $9 \mu \mathrm{g} / \mathrm{L}$ in both rivers. In 2003, the Aare transported $65 \mathrm{kt}$ of particles in $1.13 \mathrm{~km}^{3}$ of water containing $3.95 \mathrm{t}$ DRP. An additional $0.19 \mathrm{t} \mathrm{P}$ were reversibly sorbed to particles. The Lütschine transported $242 \mathrm{kt}$ of particles in $0.60 \mathrm{~km}^{3}$ of water with $1.11 \mathrm{t}$ DRP and $0.43 \mathrm{t} \mathrm{P}$ sorbed to particles. Average DRP and suspended matter concentrations were $3.4 \mu \mathrm{g} \mathrm{P} / \mathrm{L}$ and $57 \mathrm{mg} / \mathrm{L}$ (Aare) and $1.5 \mu \mathrm{g} \mathrm{P} / \mathrm{L}$ and $400 \mathrm{mg} / \mathrm{L}$ (Lütschine).

\section{Discussion}

\subsection{Surface Binding Capacities of Various Particles for Phosphate}

[28] Maximum $\mathrm{P}$ adsorption capacities $\Gamma_{\max }$ published in the literature vary over multiple orders of magnitude. They are higher for pure metal oxides and smaller for mixed minerals or organic adsorbents such as soils [Goldberg and Sposito, 1985]. The sorption tendency of $\mathrm{HPO}_{4}^{2-}$ at $\mathrm{pH}>7$ is rather low. Gomez et al. [1999] observed a transition from Fe-sorbed phosphate to organically bound phosphate when $\mathrm{pH}$ increased from 7 to 8. Experiments of Ioannou and Dimirkou [1997] and Dimirkou et al. [2002] show that the dependence of $\mathrm{P}$ sorption on the suspension $\mathrm{pH}$ is weak for hematite and kaolinite. The same results from estimations of Sigg and Stumm [1981] for goethite. Sakadevan and Bavor [1998] reported maximum adsorption capacities $\left(\Gamma_{\max }\right)$ of $1430 \mathrm{mmol} / \mathrm{kg}$ for blast furnace slag, $140-170 \mathrm{mmol} / \mathrm{kg}$ for soil samples, and $69 \mathrm{mmol} / \mathrm{kg}$ for zeolite. Fontes and Weed [1996] determined a $\Gamma_{\max }$ range of $70-160 \mathrm{mmol} / \mathrm{kg}$ for soil clays with particle sizes $<2 \mu \mathrm{m}$ and a (BET) area of $45-$ $110 \mathrm{~m}^{2} / \mathrm{g}$. For aragonite a sorption capacity of $20 \mathrm{mmol} / \mathrm{kg}$ was calculated by Millero et al. [2001]. Our values of $0.2-$ $1.7 \mathrm{mmol} / \mathrm{kg}$ (Table 3) extend this range to particulate matter from natural surface waters with significantly smaller surface areas $\left(2.1-10.2 \mathrm{~m}^{2} / \mathrm{g}\right)$ in a $\mathrm{pH}$ range important for hardwater lakes and rivers $(\mathrm{pH} 7.5-9)$.

\subsection{Comparison of Surface Sorption Constants}

[29] Sigg and Stumm [1981] suggest surface sorption constants for the sorption of phosphate to goethite of:

$$
\begin{gathered}
\mathrm{S}=\mathrm{OH}+\mathrm{H}_{3} \mathrm{PO}_{4} \Leftrightarrow \mathrm{S}=\mathrm{H}_{2} \mathrm{PO}_{4}+\mathrm{H}_{2} \mathrm{O} \quad \log \mathrm{K}_{1}^{\text {intr }}=9.5 \\
\mathrm{~S}=\mathrm{OH}+\mathrm{H}_{3} \mathrm{PO}_{4} \Leftrightarrow \mathrm{S}=\mathrm{HPO}_{4}^{-}+\mathrm{H}_{2} \mathrm{O}+\mathrm{H}^{+} \\
\mathrm{logK} \text { intr }=5.1 \\
\mathrm{~S}=\mathrm{OH}+\mathrm{H}_{3} \mathrm{PO}_{4} \Leftrightarrow \mathrm{S}=\mathrm{PO}_{4}^{2-}+\mathrm{H}_{2} \mathrm{O}+2 \mathrm{H}^{+} \quad \log \mathrm{K}_{3}^{\text {intr }}=-1.5
\end{gathered}
$$




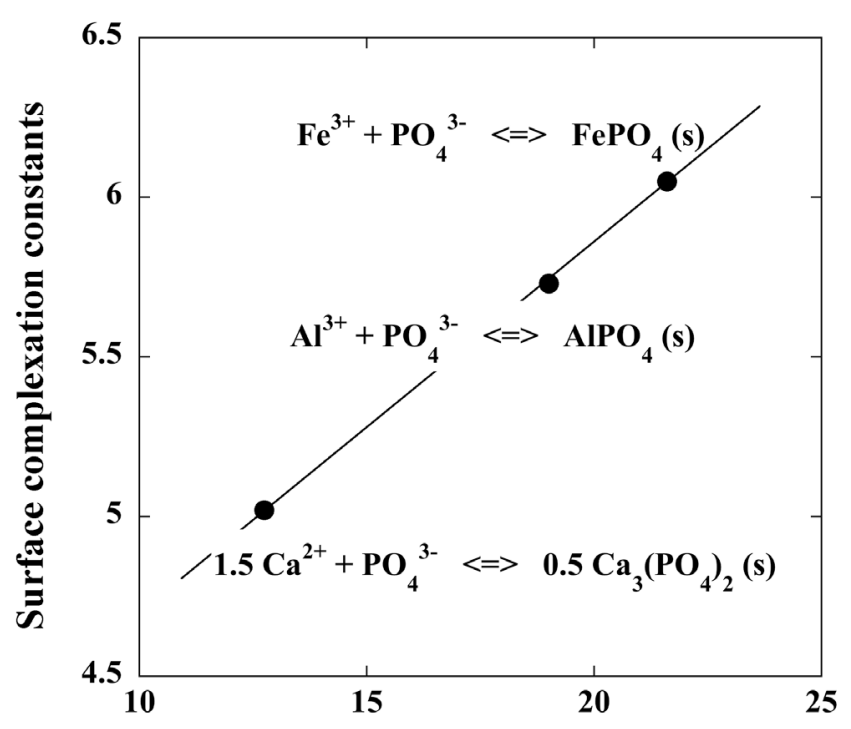

Solubility constants of phosphate minerals

Figure 3. Correlation between complexation constants of phosphate on goethite, kaolinite, and calcite, and the solubility constants of $\mathrm{FePO}_{4}$ (amorphous [Krauskopf, 1979]), $\mathrm{AlPO}_{4}$ (berlinite [Lindsay, 1979]), and $\mathrm{Ca}_{3}\left(\mathrm{PO}_{4}\right)_{2}$ (alpha [Lindsay, 1979]).

[30] The constants are intrinsic (intr), indicating their validity for zero surface charge. Previous researchers have applied these model assumptions to experiments with different particulate surfaces, which allow direct comparison of the binding constants. Dzombak and Morel [1990] critically selected the $\log \mathrm{K}^{\text {intr }}$ values of $9.59,3.69$, and -3.98 for the surface sorption to hydrous ferric oxide. Ioannou and Dimirkou [1997] introduced a model for the sorption of phosphate to kaolinite with $\log \mathrm{K}_{1}^{\text {intr }}=9.96, \log \mathrm{K}_{2}^{\text {intr }}=4.78$ and $\log \mathrm{K}_{3}^{\mathrm{intr}}=-0.87$. These parameters suggest a weak dependence of $\mathrm{P}$ sorption on the $\mathrm{pH}$ of the suspension.

[31] In natural waters of $\mathrm{pH} 7.2$ and higher, $\mathrm{HPO}_{4}^{2-}$ is the dominating DRP species. In order to compare the intrinsic constant given in equation (10) with the sorption constants observed in this study $\left(\log \mathrm{K}_{\mathrm{DRP}}=5.6\right.$ to 7.1$)$, 'conditional' constants for natural $\mathrm{pH}$ values had to be derived. Including the $\mathrm{pH}$ in equation (10) and using the appropriate species instead of $\mathrm{H}_{3} \mathrm{PO}_{4}$, we obtained constants that are comparable to the sorption constants observed in our experiments. At a $\mathrm{pH}$ of 8.4 the conditional constants $\log \mathrm{K}^{\text {cond }}$ for phosphate adsorption to goethite and kaolinite are 6.05 and 5.73, respectively. Millero et al. [2001] determined a log $\mathrm{K}^{\text {cond }}$ of 5.02 for the adsorption of phosphate to aragonite at $15{ }^{\circ} \mathrm{C}$ and zero salinity. These values follow the general trend of the affinity of phosphate toward the complexing cation or the series of solubility constants. A correlation between the adsorption of cations to a specific particulate surface, and the logarithm of their first hydrolysis constant is well known [Schindler and Stumm, 1987]. The correlation between the logarithms of surface-binding constants and minerals of phosphate with the corresponding cation (Figure 3) is a consequence of the inner sphere character of the adsorbed phosphate. The agreement of our modeling results, derived from field data, with theoretical descriptions of phosphate sorption generates a management tool for water quality in phosphate-limited oligotrophic systems.

[32] The somewhat higher $\log \mathrm{K}$ values observed in our experiments may originate from the low fraction of potentially possible surface coverage with phosphate, thus not occupying a representative area of the whole mineral but instead preferentially those surface sites with the highest binding energies (where kinks and steps in the lattice may be more reactive than face sites [see Stumm, 1992]). Also, other $\mathrm{Fe}-\mathrm{PO}_{4}$ minerals with higher solubility products than amorphous $\mathrm{FePO}_{4}$ (e.g., strengite, $\log \mathrm{Ks}_{0}=26.4$ [Krauskopf, 1979]) continue the correlation with our surface-binding constants of Figure 3 and may indicate the presence of $\mathrm{Fe}$ minerals that allow more preferable steric and/or electrostatic conditions for the adsorption of phosphate. However, we did not observe correlations between the surface sorption capacities and the Fe content in our set of particle samples. This is likely because the sorption of phosphate is related to the concentrations of iron oxyhydroxides and only a small fraction of the particulate iron is accessible for surface complexation.

\subsection{Sorption of Phosphate to Aquatic Particles in Natural Waters}

[33] Because of the tendency of dissolved P (DP) to sorb to solids, the DP present in the water column is not necessarily identical with the DP available to the biota, as, depending on the concentration and quality of suspended particles, a significant fraction of potentially available $P$ may be sorbed to the particle surfaces. The adsorption isotherms presented in Figure 4 show for selected TDP concentrations (1-300 $\mu \mathrm{g} \mathrm{P} / \mathrm{L})$ how the fraction of dissolved P decreases

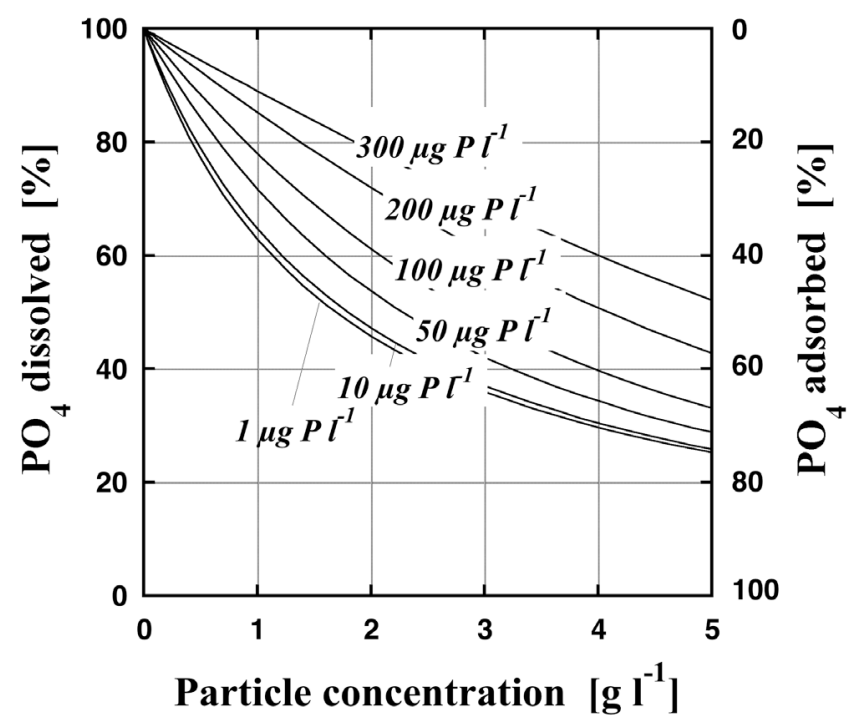

Figure 4. Model calculation of the distribution of phosphate between particulate surfaces and solution. Dissolved fractions of phosphate in percent (available to direct analysis) were calculated for total phosphate concentrations of $1,10,50,100,200$, and $300 \mu \mathrm{g} \mathrm{P} / \mathrm{L}$ at $\mathrm{pH} 8.4,1 \mathrm{mmol} / \mathrm{L}$ alkalinity, and $0.5 \mathrm{mmol} / \mathrm{L} \mathrm{Ca}^{2+}$ for increasing particle concentrations. Sorption parameters from river particles $\left(\log \mathrm{K}_{\mathrm{TDP}}=5.82, \Gamma_{\max }=1.35 \mathrm{mmol} / \mathrm{kg}\right)$ were used as presented in Table 3. Electrostatic effects on the sorption process were not considered. 

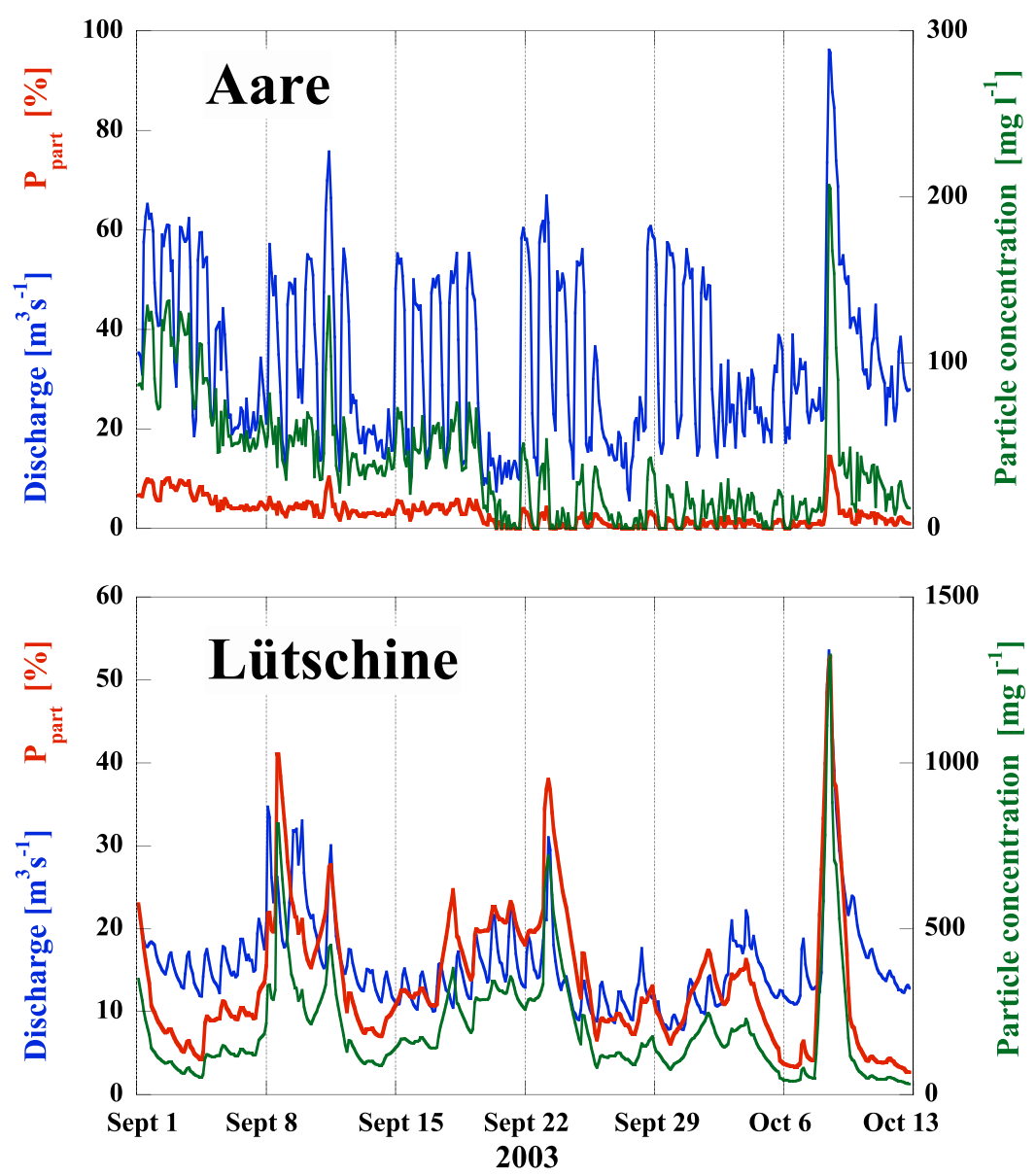

Figure 5. Transported bioavailable $\mathrm{P}$ (calculated) in Aare and Lütschine, which is sorbed to particulate surfaces in percent of the total bioavailable $\mathrm{P}$ (red line). Model assumptions were $\log \mathrm{K}_{\mathrm{DRP}}=5.82, \Gamma_{\max }=$ $1.34 \mathrm{mmol} / \mathrm{kg},\left[\mathrm{Ca}^{2+}\right]=0.5 \mathrm{mmol} / \mathrm{L},\left[\mathrm{HCO}_{3}^{-}\right]=1 \mathrm{mmol} / \mathrm{L}$ and $\mathrm{pH}=8.4$. The blue line depicts the monitored hydrological discharge $\mathrm{Q}[\mathrm{m} 3 / \mathrm{s}]$, and the green line shows the particle concentration (right scale), as calculated from $\mathrm{Q}$ using the rating curve relation between $\mathrm{Q}$ and particle concentration [Finger et al., 2006]. (top) River Aare. (bottom) River Lütschine.

when the particle concentration increases. Figure 4 depicts the fractions of sorbed and dissolved $\mathrm{P}$ as a percentage of the total $\mathrm{P}$ potentially available to biota. It is applicable to natural surface waters containing particles low in organic carbon and $\mathrm{Fe}$-(oxy)hydroxides.

\subsection{Consequences for the P Budget of Downstream Waters}

[34] In 2003, the two major contributors Aare and Lütschine carried an annual load of $307 \mathrm{kt}$ of mineral particulate matter to Lake Brienz. In such situations, the conventional DRP or TDP analyses may severely underestimate the lake's load with bioavailable $\mathrm{P}$, as in the river water a significant fraction may be overlooked by neglecting reversible surface sorption. However, while the rivers enter the lake and distribute their particle load, due to the sudden particle dilution part of the reversibly sorbed $\mathrm{P}$ will desorb from the particles, as can be derived from Figure 4.

[35] For illustration, Figure 5 presents water discharge and particle concentration observed in the Aare and Lütschine during a period of six weeks in 2003. For an estimation of $\mathrm{P}$ speciation, i.e., the distribution of potentially bioavailable $\mathrm{P}$ between solution and particles, we applied the constants from Table $3\left(\log \mathrm{K}_{\mathrm{TDP}}=5.82, \Gamma_{\max }=1.34 \mathrm{mmol} / \mathrm{kg}\right)$ and include $0.5 \mathrm{mM} \mathrm{Ca}^{2+}, 1 \mathrm{mM} \mathrm{HCO}_{3}^{-}$. In the Aare, because of hydropower peaking, the regular daily fluctuations in water discharge often reached or even exceeded $40 \mathrm{~m}^{3} / \mathrm{s}$, whereas in the Lütschine, because of snowmelt periodicity, they only amounted to about $5 \mathrm{~m}^{3} / \mathrm{s}$. Whereas within the drainage area of the Aare on average $232 \mathrm{kt}$ of particulate matter is trapped annually in the various reservoirs while no such reservoirs exist in the catchment of the Lütschine, the average particle concentration of the Lütschine exceeded that of the Aare by a factor of 1.9 (note the different scales for particle concentration and water discharge in Figures 5, top, and 5, bottom).

[36] In the Aare, where particle concentrations were 0$50 \mathrm{mg} / \mathrm{L}$ and DRP concentrations were around $2 \mu \mathrm{g} / \mathrm{L}$, less than $10 \%$ of the potentially bioavailable $\mathrm{P}$ was sorbed to particle surfaces except during a short rain event on October 9 when the particle concentration increased to over $200 \mathrm{mg} / \mathrm{L}$ and the sorbed fraction of bioavailable $\mathrm{P}$ exceeded $10 \%$ during a limited period of time (Figure 5, top). In the Lütschine the particle concentration always exceeding $50 \mathrm{mg} / \mathrm{L}$, was $400 \mathrm{mg} / \mathrm{L}$ on average [Finger et al., 2006] and regularly exceeded $1500 \mathrm{mg} / \mathrm{L}$ during flood events. As a consequence, $50 \%$ or more of the potentially bioavailable $\mathrm{P}$ was sorbed to particles during peak flow. 
[37] For 2003 we calculated averages of $7.4 \%$ and $24.8 \%$ of the total bioavailable $\mathrm{P}$ that were transported reversibly sorbed to particles in the Aare and Lütschine. As the percentage of bioavailable $\mathrm{P}$ that is transported associated with particles increases with decreasing DRP and with increasing particle concentration, the conventionally determined DRP load may substantially underestimate the effective load with bioavailable $\mathrm{P}$ in unpolluted but turbid rivers. As shown in Table 3, each $\mathrm{kg}$ of mineral particles collected from unpolluted reservoirs contained $0.41 \mathrm{mmol}$ of desorbable P. Thus, taking into account that the reservoir annually trapped $232 \mathrm{kt}$ of particulate matter [Finger et al., 2006] and that an estimated $2 / 3$ of it has a grain size comparable to the material we investigated, they also retained $2.0 \mathrm{t} / \mathrm{yr}$ of potentially bioavailable $\mathrm{P}$ that otherwise would have been loaded to Lake Brienz.

\section{Conclusions}

[38] In summary we conclude the following.

[39] 1. In unpolluted rivers with a high content of suspended mineral particles $(>50 \mathrm{mg} / \mathrm{L}) \mathrm{P}$ loads solely based on DRP measurements may substantially underestimate their true loads with bioavailable $\mathrm{P}$ to downgradient lentic environments.

[40] 2. For the P-limited, oligotrophic lakes considered in this study, modeling P sorption onto a single type of surface site adequately described trends in the field data. The maximum sorption capacity and conditional sorption constants of mineral particles for phosphate are in the order of $\Gamma=1 \mathrm{mmol} / \mathrm{kg}$ and $\log \mathrm{K}=6$, respectively, and are nearly independent of the particles' organic carbon $(0.1-0.34 \mathrm{~mol} / \mathrm{kg})$ and iron $(0.6-0.9 \mathrm{~mol} / \mathrm{kg})$ content.

[41] 3. The parameters given may generally be applied for mineral weathering suspended matter. However, sorption experiments should be extended to particulate matter from a larger variety of aquatic systems in order to gain a more systematic view of the sorption behavior of phosphate toward natural aquatic particles.

[42] Acknowledgments. A great many people helped to accomplish the experiments and contributed with theoretical and practical help to this work. We are grateful to David Finger, Martin Schmid, Markus Zeh, Catherine Hoyle, Wisi Zwyssig, Mike Sturm, René Gächter, Thomas Haltmeier, David Kistler, Hermann Mönch, and Michael Meyer. Christine Vollenweider and Henriette Studer performed the sampling of the Aare and Lütschine. Two anonymous reviewers and an associate editor helped to improve the manuscript. The present study is part of an interdisciplinary research project investigating the ecological impacts of anthropogenic changes in the watershed of Lake Brienz. The study was funded by (1) Regional Government of Canton Bern, (2) KWO Grimselstrom, (3) Swiss Federal Office of Environment (FOEN), (4) shoreline communities of Lake Brienz, and (5) Swiss Federal Institute of Aquatic Science and Technology (EAWAG).

\section{References}

Anselmetti, F., R. Bühler, D. Finger, S. Girardclos, A. Lancini, and M. Sturm (2006), Erosion, particle transport and sedimentation between Grimsel and Brienzersee, Aquat. Sci, in press.

Ashley, K., L. C. Thompson, D. C. Lasenby, L. McEachern, K. E. Smokorowski, and D. Sebastian (1997), Restoration of an interior lake ecosystem: The Kootenay Lake fertilization experiment, Water Qual. Res. J. Can., 32, 295-323.

Baldwin, D. S., A. M. Mitchell, and G. N. Rees (2000), The effects of in situ drying on sediment-phosphate interactions in sediments from an old wetland, Hydrobiologia, 431, 3-12.

Cohn, T.A. (1995), Recent advances in statistical methods for the estimation of sediment and nutrient transport in rivers, U.S. Natl. Rep.
Int. Union Geod. Geophys. 1991-1994, Rev. Geophys., 33, 11171123.

Colombo, C., V. Barron, and J. Torrent (1994), Phosphate adsorption and desorption in relation to morphology and crystal properties of synthetic Hematites, Geochim. Cosmochim. Acta, 58, 1261-1269.

Deutsche Einheitsverfahren zur Wasseruntersuchung (1996), Deutsche Einheitsverfahren zur Wasseruntersuchung, vol. 2, Wiley-VCH, Weinheim, Germany.

Dimirkou, A., A. Ioannou, and M. Doula (2002), Preparation, characterization and sorption properties for phosphates of hematite, bentonite and bentonite-hematite systems, Adv. Colloid Interface Sci., 97, 37-61.

Dzombak, D. A., and F. M. M. Morel (1990), Surface Complexation Modeling, John Wiley, Hoboken, N. J.

Finger, D., M. Schmid, and A. Wüest (2006), Effects of upstream hydropower operation on riverine particle transport and turbidity in downstream lakes, Water Resour. Res., 42, W08429, doi:10.1029/2005WR004751.

Fontes, M. P. F., and S. B. Weed (1996), Phosphate adsorption by clays from Brazilian Oxisols, relationships with specific surface area and mineralogy, Geoderma, 72, 37-51.

Fox, I., and M. A. Malati (1993), An investigation of phosphate adsorption by clays and its relation to the problems of eutrophication of the River Stour, Kent, J. Chem. Technol. Biotechnol., 57, 97-107.

Gächter, R., S. M. Steingruber, M. Reinhardt, and B. Wehrli (2004), Nutrient transfer from soil to surface waters: Differences between nitrate and phosphate, Aquat. Sci., 66, 117-122.

Goldberg, S. (1985), Chemical modeling of anion competition on goethite using the constant capacitance model, Soil Sci. Soc. Am. J., 49, 851-856.

Goldberg, S., and G. Sposito (1985), On the mechanism of specific phosphate adsorption by hydroxylated mineral surfaces: A review, Commun. Soil Sci. Plant Anal., 16, 801-821.

Gomez, E., C. Durillon, G. Rofes, and B. Picot (1999), Phosphate adsorption and release from sediments of brackish lagoons: $\mathrm{PH} \mathrm{O}_{2}$ and loading influence, Water Res., 33, 2437-2447.

Gustafsson, J. P. (2001), Modelling competitive anion adsorption on oxide minerals and an allophane-containing soil, European J. Soil Sci., 52, $639-653$.

Ioannou, A., and A. Dimirkou (1997), Phosphate adsorption in hematite, kaolinite, and kaolinite-hematite (k-h) systems as described by a constant capacitance model, J. Colloid Interface Sci., 192, 119-128.

Kelts, K., U. Briegel, K. Ghilardi, and K. Hsü (1986), The limnogeologyETH coring system, Schweiz. Z. Hydrol., 48, 104-115.

Krauskopf, K. B. (1979), Introduction to Geochemistry, 2nd ed.,McGrawHill, New York.

Lambert, D., and W. Mahler (1995), An evaluation of the efficiency of the alkaline persulphate digestion method for the determination of total phosphorus in turbid waters, Water Res., 29, 7-9.

Lindsay, W. L. (1979), Chemical Equilibria in Soils, John Wiley, Hoboken, N. J.

Millero, F., F. Huang, X. R. Zhu, X. W. Liu, and J. Z. Zhang (2001), Adsorption and desorption of phosphate on calcite and aragonite in seawater, Aquat. Geochem., 7, 33-56.

Moosmann, L., B. Müller, R. Gächter, A. Wüest, E. Butscher, and P. Herzog (2005), Trend-oriented sampling strategy and estimation of soluble reactive phosphorus loads in streams, Water Resour. Res., 41, W01020, doi:10.1029/2004WR003539.

Müller, B. (2004), ChemEQL V3. 0, a program to calculate chemical speciation equilibria, users' manual, Swiss Fed. Inst. of Aquat. Sci. and Technol., Kastanienbaum, Switzerland. (Available at http://www.eawag.ch/ research_e/surf/Researchgroups/sensors_and_analytic/chemeql.html)

Müller, B., and A. Duffek (2001), Similar adsorption parameters for trace metals with different aquatic particles, Aquat. Geochem., 7, 107-126.

Nollet, L. M. L. (2000), Handbook of Water Analysis, Marcel Dekker, New York.

Organisation for Economic Co-operation and Development (1982), Eutrophisation des eaux: Méthodes de surveillance, d'évaluation et de lutte, Paris.

Pacini, N., and R. Gächter (1999), Speciation of riverine particulate phosphorus during rain events, Biogeochemistry, 47, 87-109.

Sakadevan, K., and H. J. Bavor (1998), Phosphate adsorption characteristics of soils, slags and zeolite to be used as substrates in constructed wetland systems, Water Res., 32, 393-399.

Schindler, D. W. (1977), The evolution of phosphorus limitation in lakes, Science, 195, 260-262.

Schindler, P. W., and W. Stumm (1987), The surface chemistry of oxides, hydroxides, and oxide minerals, in Chemical Processes at the ParticleWater Interface, edited by W. Stumm, pp.83-11, John Wiley, Hoboken, N.J. 
Sigg, L., and W. Stumm (1981), The interaction of anions and weak acids with the hydrous goethite ((-FeOOH) surface, Colloids Surf., 2, 101-117.

Stockner, J. G., and E. A. Macisaac (1996), British Columbia lake enrichment programme: Two decades of habitat enhancement for Sockeye Salmon, Reg. Rivers Res. Manage., 12, 547-561.

Stone, M., and A. Mudroch (1989), The effect of particle size, chemistry and mineralogy of river sediments on phosphate adsorption, Environ. Technol. Lett., 10, 501-510.

Stumm, W. (1992), Chemistry of the Solid-Water Interface, John Wiley, Hoboken, N. J.
Stumm, W., and J. J. Morgan (1996), Aquatic Chemistry, 3rd ed., WileyInterscience, Hoboken, N. J.

Wenzel, R. G. (2001), Limnology: Lake and River Ecosystems, 3rd ed., Elsevier, New York.

B. Müller, R. Stierli, and A. Wüest, Surface Waters-Research and Management, EAWAG, CH-6047 Kastanienbaum, Switzerland. (beat. mueller@eawag.ch) 